\title{
THE FUNCTIONING OF THE COLLECTIVE MEMORY OF LOWER SILESIANS WITHIN THE MULTICULTURAL COMMUNITY OF BORNE SULINOWO
}

Andrzej MONIAK

\section{ABSTRACT}

In the context of multiculturalism, the processes of seeking and creating of collective identity of the local community are quite specific. In these processes, it is the collective memory that plays a major role as a deciding and organizing factor of the integration of the community at all levels. A town unique - Borne Sulinowo - has existed within the state borders for only 21 years now. In the past, it was a military base of for the Third Reich, and after the World War II, it served as a military base for Soviet Army. The community of Borne Sulinowo is still in the process of seeking of its identity and its place in history. In 1993, when the town was created and organized, the prospective citizens came from 36 regions of Poland. The interesting process of entering of incoming people into the new achitectural and cultural space, the space which never belonged to the cultural heritage of Poland, has begun. People from different backgrounds, differentiated in view of the place where they came from, in view of age, profession, education and life experience, were trying to accustom the new space. The process of shaping the local community in Borne Sulinowo is still in progress and has not finished yet. One of the major factor that influence the above mentioned process is the collective memory of particular groups of people, such as the groups from Upper and Lower Silesia or Western Pomerania.

\section{KEYWORDS:}




\section{INTRODUCTION}

This paper aims to describe and analyse the functioning of collective memory in the multi-cultural community of Borne Sulinowo. Borne Sulinowo is a town in West Pomeranian Voivodship in Poland. It was granted the town status in 1993 by the decision of the Council of Ministers of Poland and so is the newest town in Poland; for various reasons, it is also unique. The community of Borne Sulinowo was formed in the period of system transformation in Poland, which is not insignificant for its social and cultural view. For 22 years, Borne Sulinowo has been seeking its place in the recent history of Poland and is still creating its social and cultural identity as a modern Pomeranian local community. Both processes are accompanied by various events and social situations. The reasons for both are many: varied attitudes of inhabitants to the existing cultural heritage, foreign and non-typical urban space in which the everyday existence of the inhabitants takes place, various treatment and evaluation of the town's past, usually through the lens of experiences gathered in the previous place of residence, and various attitudes towards the prospects and developmental plans of the town. Therefore, the town community is in the constant phase of formation, structural changes, including internal integration and internal transformation, as the inhabitants say themselves. It can be assumed that Borne Sulinowo is a performatic local community, i.e., one shaped "here and now". Borne Sulinowo is a town of delayed independence: it actually did not re-join the country's administration until 1992, when the last transport of Russian Federation soldiers stationed here left on 2 October.

The deserted, undamaged urban space, set in a clean, unspoiled natural environment, amongst rich fauna and flora of the neighbouring woods and lakes was meant to be like an Eldorado for people coming from all around Poland. Alas, the mistakes of the administrative authorities of the time and the lack of help from the central authorities left a disputed trace until this day, influencing the present-day processes of the local community.

The history of a town plays an important role in the shaping of its local community, as well as the attitude of the inhabitants to its remembered recent history, understood as a collective memory. Many anthropological, sociological, and philosophical theories tell us that a collective memory is among the most important factors to determine the formation processes and functioning of a local community. A collective memory, entangled in various social and cultural contexts, is constantly being selected and reorganised; therefore, it contributes to deciding on the future of the town and its development opportunities, and places it in the culturally diverse regional space of West Pomerania. This raises the question whether there is a common collective 
memory, shared by all the inhabitants of the town, whether the town's community is a community of memory or rather a diversity of collective memory can be seen, which has a negative effect on internal social processes.

Collective memory, tradition, identity, heritage, and cultural continuity are areas which form a connective structure fusing every social group, including local and regional communities, endowing them with a proper world of meanings and thus setting the framework of collective experience. Every social group, from the national community to the smallest collective forms, asks the question what must not be forgotten.

In the words of the French philosopher Pierre Nora, every community is actually a community of memory.

It is worth adding that Borne Sulinowo is not the only town entangled in the recent history of Poland which writes its history anew. Other towns similar in this regard are Kęszyca near Międzyrzecz, Tomaszowo near Żagań, Świętoszów, and Chojna near Gryfino. All the above had, until recently, been garrison towns where Polish and Soviet military units were stationed, with this exception that all of them were under the administration of the Polish state, unlike Borne Sulinowo, which was exempt from the Polish jurisdiction. Was this fact significant for the formation of collective memory in the community of Borne Sulinowo? It would seem that in Borne the memory of the past is focused on forgetting, contrary to the towns listed above and their inhabitants, who want to creatively use what was left of the not-so-distant past, even as a tourist attraction. Exploring the issue of post-garrison towns, quite numerous in West Pomerania, Lubusz, and Lower Silesia, gives rise to more and more questions to which we do not know the full answers.

The contents of the article comprise the results of two years of the author's research, carried out in 2010-2014 in Borne Sulinowo, mainly using standard research techniques and methods typical of anthropological and sociological studies.

\section{THEORETICAL ASSUMPTIONS}

The functioning of collective memory and the formation of a community of memory is among the most important questions in the culturological analysis of every loca, regional, and national community. It is particularly so if the given community is in the stage of formation and constructing its identity. Beyond doubt, Borne Sulinowo is one such community. As the majority of theories in cultural anthropology and sociol-

1 J. Assmann, Pamięć kulturowa. Pismo, zapamiętywanie i polityczna tożsamość w cywilizacjach starożytnych [Cultural memory and early civilisation: Writing, remembrance, and political imagination], transl. by A. KryczyńskaPham, Warszawa 2008, p.46. 
ogy say, carrying out an analysis of the formation of a local community requires taking into account the historical conditions in which the studied community is formed, since the experience of historical time is made present in what is "here and now". The uninterrupted chain of events in which social individuals and groups participate are evaluated, perceived, and used in various ways. Subsequently, history becomes a specific determinant of the present and future of a social group.

The experience of historical past in cultural sciences takes on many variants and configurations. These include heritage of the past, tradition, historical memory, as well as remembered history and collective memory. All the above categories, while similar to one another (as they refer to the past), differ in the meaning and functions they serve in human communities. They are necessary for the generational transfer of culture to take place. Thus, it is worth to present, in short, the meaning scope of the categories used to analyse the problem described below.

Heritage (or, more precisely, cultural heritage) has become a very trendy term, frequently used in journalism, including scientific and popular scientific journalism. The meaning scope of the heritage term is very wide, making it fairly imprecise. Cultural heritage comprises all the assets of material and immaterial culture (immaterial cultural heritage) of a given group or geographical area, not excluding its natural environment. Heritage performs the cumulative and transmission function of a culture, showing the collected achievements of past generations and past times. While cultural heritage cannot be changed, it can be forgotten, which still proves to be difficult in social practice. Since cultural heritage contains achievements of generations, it is a common good which is protected by the law as well, as exemplified by the civilisational heritage of nations, continents, or all humanity.

The term more frequently found in ethnological and ethnographic literature is tradition.

There are many theories explaining the notion of cultural tradition in the literature of the subject, making it very useful in the empirical studies of socio-cultural processes. Numerous definitions of cultural tradition say that "tradition" is an equivocal and complex notion. In social reality there are many kinds of cultural tradition, which serve different functions regarding the cultural system.

Robert Redfield, a classical writer of ethnology, distinguishes between "great" and "little traditions". The so-called great tradition is passed down in writing, also by educational institutions, schools, universities, the Church. It is maintained by social elites. Whereas the little tradition is the tradition of peasants, belongs to various so-

2 Stownik etnologiczny. Terminy ogólne [Ethnological dictionary: General terms], ed. by Z. Staszczak, WarszawaPoznań 1987, p. 55. 
cial strata and classes, local and regional communities. Marcel Mauss distinguishes oral tradition as a way to pass down gestures and manual activities. The tradition understood so is transmitted during the socialisation of an individual. ${ }^{3}$ In turn, Kazimierz Dobrowolski understands tradition as the whole of the legacy passed by the generations stepping down to the ones taking over. ${ }^{4}$ While the valuable book by Jerzy Szacki, Tradycja: Przeglad tematyki, which inspired much research into tradition, was published quite a long time ago, the understanding of tradition it suggests still seems to be accurate. Szacki distinguishes between three meanings of the term: tradition in its objective meaning, as the material achievement of generations; tradition in its functional meaning, as the transmission of cultural goods itself; and tradition in its subjective meaning, involving the positive or negative attitude towards the transmitted cultural goods. ${ }^{5}$ As a socio-cultural category, tradition is not emotionally neutral, it can be accepted or rejected, and so is subject to assessment and evaluation. It servers many functions towards the social group. The most important is the transmission of culture, ensuring cultural continuity. Moreover, tradition provides the sense of stabilisation, of one's own value, thus ensuring and strengthening the cultural identity of every society. It is also an important component of the process of socialisation and education of the generation entering adulthood. Being a temporal category, tradition links the past with the present, makes the past present in the now. The fundamental criterion which determines it is its suitability for the socio-cultural system. It means that not the content but rather a social need is the constitutive quality of tradition. Already quoted above, Szacki writes that "tradition is the transformation of ambiguous facts of the past into unequivocal values of the present". There is ample evidence that tradition is not opposed to the present, is subject to evaluation and selection, and is not necessarily conflicted with modernity. It is beyond doubt, however, that it serves well in the observation analysis of all cultures as a research category.

The next form of experiencing historical time is remembered history, often called historical memory. The carriers of historical memory are people and their consciousness. Remembered history is also a reference to the past, an evaluative stance towards the past. The theoretical basis of remembered history can be founds in the works of, among others, well-known German historian and philosopher of history Reinhart Kosseleck, French philosopher Paul Ricoeur, who wrote about the phenomenon of memory (in his discussion of human existence and understanding), and French

3Stownik etnologiczny. Terminy ogólne, ed. by Z. Staszczak, Warszawa-Poznań 1987,p. 354.

4 K. Dobrowolski, Studia nad życiem spotecznym i kultura [Studies into social life and culture], WrocławWarszawa-Kraków 1966, p. 77.

5 J. Szacki, Tradycja. Przegląd problematyki [Tradition: A survey of the topic],Warszawa 1971, p. 140-147.

6 J. Szacki, Tradycja. Przegląd problematyki,Warszawa 1971 p. 154-155. 
historian Pierre Nora, who wrote about identity and memory. Somewhat earlier, the issued of historical memory was also raised by Lucien Febvere, founder and co-creator of the Annales School.

Koselleck introduced two notions into science: the so-called primary history and secondary history. According to him, primary history is the objective scientific historical knowledge, whereas secondary history is the collective historical memory. ${ }^{7}$ In other words, primary history functions as a science about the past, is an objective state of knowledge at a given point in time, and teaches us to maintain an attitude of reflection towards the past and to distance ourselves from assessing and interpreting past events with too much haste. Remembered history is also knowledge of the past, yet it is the emotional, evaluative layer, which predominates there. Thus, remembered history refers to individual experience as well as collective experience of a specific social group. Consequently, besides the notion of history as a branch of knowledge, there is the notion of historical memory, or remembered history. What then is the difference between the two, as they relate to the past? How do they differ in the description and interpretation of the past? Can historical memory, being a peculiar interpretation of history, affect the present and the future?

History understood as a science enters the consciousness of an individual and of a group from the outside, so to say. Moreover, history defined so always exceeds historical memory, or remembered history. The latter, according to Ricoeur, is only a component of the former, not always meticulously used and sometimes even rejected as having nothing in common with history. This outstanding philosopher recognises the disturbing, recently visible phenomenon: it is the relation between history and memory which takes the form of difficult to eliminate social conflicts.

When memory replaces history, and history forgets about memory, both memory and history can be put to various uses and serve various purposes. Paul Valery says that the past, whether more or less fantastic or more or less ordered, affects the future after the fact with as much power as the present. ${ }^{8}$ Without history, there would be no directed political, social, or cultural change. All changes originate in dynamic consciousness, which would not exist without historical reflection. Jerzy Topolski writes that history, in the sense of an account of events and in the sense of memory, accompanies humans like a shadow. Without it, we are unable to understand the meaning of the present or the changes of the future. ${ }^{9}$ History as a science and remembered history have an extraordinary power to integrate the social collective, they are a foundation of

7 R. Koselleck, Semantyka historyczna [Historical semantics], transl. by W. Kunicki, Poznań 2012, p. 73-79.

8 T. Delpech, Powrót barbarzyństwa w XXI wieku, [Back to barbarism], transl. by W. Dluski, Warszawa 2008, p. 153.

9 J. Topolski, Świat bez historii [World without history], Poznań 1998, p. 7. 
identity. It is worth adding that history and historical memory present themselves as multidimensional, often chaotic and ambiguous images. Varied, sometimes extremely different interpretations of events attest to the conflict between humans and history. Both "interlocutors" are increasingly remote from each other.

The category of experiencing historical time most interesting to us is "collective memory". Similarly to the ones discussed above, the category of collective memory is an ambiguous notion, sometimes even controversial. In this case, however, ambiguity is not a drawback. To the contrary, it allows viewing the studied socio-cultural reality from many sides, facilitating the understanding of processes occurring within. As in humanities strictly defined and precise notions narrow the possible scope of interpretation of social phenomena, it is not ambiguity or controversy that are problematic but rather the limits of ambiguity, since the latter does not mean arbitrariness. There are two extreme positions regarding collective memory. Some scholars, sociologists, ethnologists, historians, and philosophers, have doubts over the existence and usefulness of this notion, claiming that only individual, isolated memory exists. Others treat the collective memory as a social fact which expresses a piece of knowledge regarding the past and an attitude of evaluation towards what is past. Maurice Halbwachs, considered as the founder of modern research on collective memory, claimed that without social reference the so-called collective memory would not exist; in fact, its content is shaped by the collective. According to the scholar, memory is created in the communication process and results from internal interactions of a social group..$^{10}$ He introduced the notion of "social frameworks of memory" into science, explaining that individual memory is created in specific social contexts. He adds that while only individuals have memory, it is being shaped by the group."

This way collective memory becomes an important category of group identification: it allows one to say "us". It should also be added that the creation of collective memory is a constant process, it co-creates "images" of the past, recollections, as well as the symbolic world of meanings.

Jan Assmann, a German historian of antiquity (more precisely, an Egyptologist) introduced the notion of "cultural memory", also construed as supra-individual memory. According to him, over centuries societies construct imaginations about themselves and reproduce their own identity over generations, thus producing some culture of

$10 \mathrm{~J}$. Assmann, Pamięć kulturowa. Pismo, zapamiętywanie i polityczna tożsamość w cywilizacjach starożytnych [Cultural memory and early civilisation: Writing, remembrance, and political imagination], transl. by A. KryczyńskaPham, Warszawa 2008 p. 50.

$11 \mathrm{~J}$. Assmann, Pamięć kulturowa. Pismo, zapamiętywanie i polityczna tożsamość w cywilizacjach starożytnych [Cultural memory and early civilisation: Writing, remembrance, and political imagination], transl. by A. KryczyńskaPham, Warszawa 2008 p. 51. 
memory. ${ }^{12}$ Cultural memory transforms the actual history into the remembered history. It differs from tradition in that the latter does not account for the phenomena of forgetting and suppression. ${ }^{13}$ Cultural memory accepted and adopted by a whole social group or community forms a so-called community of memory. Examples of communities of memory are local communities, particularly if their settlement continuity is unbroken. Cultural and collective memories have an enormous impact. Memory sites as places of commemoration in the form of monuments, plaques, battlefields and cemeteries excluded from usable space function as symbolic and topographical locations. They preserve memory in a different way than items do and refer us to the past as the material carriers of memory they are, spatialising the memory. Therefore, the collective and the space comprise a symbolic community. Do the space and community of Borne Sulinowo comprise a similar whole? It may occur in the social practice that when a given community leaves its living space, moves by necessity or choice to a different place, it reproduces its symbolic locations in the new place.

Collective memory contains three basic constitutive components, which Assmann, quoted above, calls figures of memory. Namely, they are references to the time and space, to a specific social group, and reconstructivity. ${ }^{14}$ Within this article, collective memory is understood as a component of the studied community's culture. Pilot studies showed that in Borne Sulinowo there are many memories, varying both individually and regarding various regional groups. It is difficult to discuss the Borne local community as a community of memory, since the latter is still being shaped.

The starting point for detailed research on Borne Sulinowo was the external view of the town and its community as well as learning its recent history. In this light, the above choice of category for analysis is not a coincidence. It also seems relevant to supplement it with two more categories, such as "local community" and "sociocultural identity".

The expressions local community, localism, and local are all terms derived from the Latin word localis, which refers to a given place or placement in space. Local means of a place, indigenous, rooted to a place. Whereas the notion of local community is difficult to define. The number of definitions of this notions, counted among the

12 J. Assmann, Pamięć kulturowa. Pismo, zapamiętywanie i polityczna tożsamość w cywilizacjach starożytnych [Cultural memory and early civilisation: Writing, remembrance, and political imagination], transl. by A. Kryczyńska-Pham, Warszawa 2008, p. 50.

13 J. Assmann, Pamięć kulturowa. Pismo, zapamiętywanie i polityczna tożsamość w cywilizacjach starożytnych [Cultural memory and early civilisation: Writing, remembrance, and political imagination], transl. by A. Kryczyńska-Pham, Warszawa 2008, p. 16.

14 J. Assmann, Pamięć kulturowa. Pismo, zapamiętywanie i polityczna tożsamość w cywilizacjach starożytnych [Cultural memory and early civilisation: Writing, remembrance, and political imagination], transl. by A. Kryczyńska-Pham, Warszawa 2008, p. 54-55. 
fundamental ones in social sciences, is impressive. 15 The majority of the definitions, as pointed out by Szacki citing George A. Hillery, assigns three constitutive traits to a local community: territory, social interaction, and the existence of a bond between its members. ${ }^{16}$

Territory is the place where a local community is formed as well as the basis of the spatial identification of the community. Many authors stress the influence of spatial environment on the identity formation of local communities. Space has been, and is an important foundation shaping bonds between people. ${ }^{17}$

Social interactions involve a set of persons comprising a local community. They usually follow a certain pattern of repeatable reactions. The count of the set determines the frequency of interactions. With a large number of people, the variety of views rises, while the alignment of activities and formulation of objectives drops; consequently, the homogeneity of a group decreases.

Social bond as the next constitutive component of local communities is manifested in the special communication between the people who are aware of their origins, culture, common behaviour, and share the same values. ${ }^{18}$ It is characteristic of local communities that they create forms of collective life, specific to each group, based on strong bonds and social control. Being tied to a given territory such as a village, town, or region they mostly functions as groups which have produced their own organisation. A local community is also a peculiar relation of people and culture with a given place. ${ }^{19}$ Even though the perception and evaluation of local community as a social category in the globalised world of the present becomes problematic and requires a certain verification of views, local community (understood as a specific social group which is the centre of experiencing values for a person) lost none of its meaning. It is the so-called subjective dimension of locality, described by Z. Jasiewicz continuing the thoughts of Yi-Fu Tuan, the author of Space and place. ${ }^{20}$

15 S. Nurek, “Idea społeczności lokalnej w tadycji i współczesnej refleksji socjologicznej” [The idea of a local community in tradition and modern sociological reflection], in Społeczności lokalne. Szkice socjologiczne. [Local communities: Sociological essays], ed. by J. Wódz, Katowice 1986, p. 11-27.

16 J. Szacki, Historia myśli społecznej [History of social thought] vol. 2, Warszawa 1983, p. 636.

17 A.Gniazdowski, "Wspólnota i świat. Tożsamość społeczności lokalnej jako temat fenomenologii” [Community and the world: Identity of a local community as a phenomenological topic], in Oblicza lokalności.Tradycja i wspótczesność [Facets of locality: Tradition and the present], Warszawa 2006. p. 29-33.

18 J. Turowski, Socjologia. Małe grupy spoteczne [Sociology: Small social groups], Lublin 1993, p. 6.

19 Z. Jasiewicz, "Lokalizm a regionalizm a migracje. Uwagi o związkach z terytorium na Ziemiach Zachodnich i Północnych Polski” [Localism vs regionalism vs migrations: Notes on territorial ties in the Polish western and northern territories] Studia etnologiczne i antropologiczne [Ethnological and anthropological studies], vol. 2. ed. by I. Bukowska-Floreńska, Katowice 1999, p. 105.

20 Z. Jasiewicz, "Lokalizm a regionalizm a migracje. Uwagi o związkach z terytorium na Ziemiach Zachodnich i Północnych Polski” Studia etnologiczne i antropologiczne, vol. 2. ed. by I. Bukowska-Floreńska, Katowice 1999, p. 105. 
The currently predominant type of society is post-modern or, as some sociologists and anthropologists suggest, late modern society. It obviously affects the way certain social categories discussed here are understood and function. It seems that the notion of identity is equally problematic like that of local community. As the plane of both individual and collective identification, identity has recently become a problem. Zbigniew Bokszański reviews various possible theories of identity in his book Identity - interaction - group, published in 1989. He explains them and concludes that a person and a social group are constantly faced with the necessity to define themselves regarding the environment of others, asking such questions as "who am I?" or "who are we?"21

Two basic kinds of identity can be distinguished: individual and social. The basis for the shaping of an individual, personal identity is the cognitive awareness of being distinct from others. Social identity is shaped as a result of comparisons between groups and the categorisation of "us". Both personal and social identity comprise a set of traits specific to the distinctiveness of a given individual and group. Jerzy Nikitorowicz considers identity as a complex phenomenon, variable and multi-dimensional, combining the individual's personal traits with the cultural values of the group in which the individual participates. ${ }^{22}$ Identity is also defined as the quality of human existence, the ever unfinished projection of an entity, based on social and individual experience. According to Ricoeur, identity is located in time, constantly produced in the self-understanding process. ${ }^{23}$ Charles Taylor adds that identity is a result of the relation between the human and the community in which she lives. ${ }^{24}$

In a pre-modern society, it was tradition as the experience of the past which determined identity, clearly defining the norms, values, way of living, and frameworks of social behaviour. Therefore identity, which was relatively stable and unequivocal, gave a sense of security to both an individual and a group. In this sense, identity defined the stability of one's place in the world and social environment, ensuring continued existence.

In the modern and post-modern type of society, there is an identity crisis due to the innumerable social and cultural choices. Identity thus becomes something variable, passing, problematic; the foundations of identity are changing. The present creates new

21 Z. Bokszański, Tożsamość - interakcja - grupa. Tożsamość jednostki w perspektywie teorii socjologicznej [Identity - interaction - group: Identity of an individual in view of sociological theory], Łódź 1989, p. 15.

22 J. Nikitorowicz, Młodzież pogranicza kulturowego Biatorusi, Polski, Ukrainy wobec integracji europejskiej [Youth from the cultural borderline of Belarus, Poland, and Ukraine facing European integration], Bialystok 2000, p. 58.

23 P. Ricoeur, Pamięć, historia, zapomnienie [Memory, history, forgetting], Kraków 2012. p. 97.

24 Ch. Taylor, Żródła podmiotowości. Narodziny tożsamości nowoczesnej [Sources of the self: The making of the modern identity], Warszawa 2005, p. 53. 
models and types of identity in relation to changing cultural trends. They have been described and explained by Zbyszko Melosik, Anthony Giddens, and many others. ${ }^{25}$

Regardless of many theoretical concepts of identity, it remains a category in the analysis of social and cultural environment. The identity of the community of Borne Sulinowo is at the stage of being shaped by various social and cultural factors. It is beyond doubt that the studied local community of the town had many regional identities, if only due to the regional groups which made it up. However, the fundamental question I will attempt to answer further in the article is to what extent the Borne community feels rooted in the new place. Does it have that feeling? Does it have a sense of belonging to the place of its existence?

The questions found in this section of the article are the skeleton of empirical studies seeking answer to the basic question if the differences in operation of collective memory and the weight of the so-called imported tradition do not hinder the inhabitants of Borne from finding a place in history and identity of their own.

\section{BIRTH OF A TOWN}

Borne Sulinowo attained its town status by the decision of the Council of Ministers of the Republic of Poland on 15 September 1993. The official ceremony took place on 7 October that year. ${ }^{26}$. The new inhabitants of the undeniably newest town in Poland entered an unusual urban space. It was not a town built for a civilian populace: it was shaped for the needs of the army. What happened earlier, before 1993? As part of the militarisation of Pomerania and East Prussia, the preparation of military practice areas of the Third Reich began in 1933. The so-far peaceful villages of Linde and Gross Born had to disappear, replaced by a garrison town and an adjacent practice area, one of the largest in the Third Reich. The space was filled with barracks, depots, fuel stations, grand villas for officers, cinemas, a hospital, a post office, and other objects. Some great (historical) generals of the German army stayed in Gross Born during that time: General Heiz Guderian, Johan von Blaskovitz, co-author of the plan to attack Poland, General Erwin Rommel, commander of the panzer corps in Africa, Fedor von Bock, commander of Army Group North, which attacked Poland on 1 September 1939 towards Torun, Świecie, and Bydgoszcz. In the beginning of the war, a POW camp, the Oflag II D, was established near Gross Born between

25 Z. Melosik, "Wychowanie obywatelskie: nowoczesność, ponowoczesność” [Civic education: Modernity, post-modernity], in Z. Melosik, K. Przyszczypkowski, Wychowanie obywatelskie: Studium teoretyczne, porównawcze i empiryczne [Civic education: A theoretical, comparative, and empirical study], Toruń-Poznań 1989, p. 45-51.

26 Journal of Laws of the Republic of Poland (Dz.U.) 1993, No. 86, item 400. 
Westfalenhof (now Kłomino) and Raderitz (now Nadarzyce village). Prisoners of war from various armies were held there: French, British, Yugoslavian, Italian, Belgian, and Polish. The list of Poles includes such well-known names as Leon Kruczkowski, Jan Nowak Jeziorański, Jan Zamojski (a visual artist, well-known before the war), and many others, as well as the survivors of Warsaw Uprising, brought there after its fall. After the end of World War II, in June 1945, Marshal Konstantin Rokossovsky was tasked with deploying Soviet troops in Poland. Make-up, numbers, or deployment of these troops were not disclosed to the Polish authorities. The Russians occupied selected military sites, including the whole Gross Born. The deployment of the foreign army was not regulated by any law, and the Polish and Soviet authorities did not sign any agreement on the legal status of Soviet troops before 1956. The fiction was thus made legal.

Since 1945, Borne Sulinowo was the headquarters of the 6th Soviet Guards Vitebsk-Novgorod Mechanised Division of the Red Army, part of the Northern Group of Forces, counting 25 thousand soldiers plus their families. Beyond doubt, it was the largest group of foreign soldiers on the Polish soil. The Russians took over the entirety of objects left by the German army, developing the garrison over the years. The area of the town and adjacent practice area was exempt from Polish law. No access was permitted to the town and surrounding woods. As a military town, Borne Sulinowo was very well equipped. Besides strictly military objects, in Borne there were residential buildings, old German officer villas, a hospital, 26 cinemas, as well as stores and other service buildings. The magnificent "Officer House" building survived and the cinema theatre in which a troupe from the Bolshoi Theatre performed every two months. The transformation in Europe and the dissolution of the Soviet Union in 1991 led to the withdrawal of the great army from Poland. The first soldiers left the town in the middle of 1991, and the last transport of the Mechanised Division soldiers, of the Russian Federation already, left on 21 October 1992 . The town was taken over by 400 soldiers from the 41st Regiment of the Polish Army to secure the premises before the town could be handed over to the civilian authorities in June 1993. By May 1993, the Silnowo Municipal Office had received some 1,300 applications for housing from people declaring they wanted to settle in the new place. Thirty families from neighbouring villages settled until the end of July 1993. ${ }^{27}$ One could say that a new stage in the history of the town began for Borne Sulinowo. Howver, it did not resemble the resettlement of the western and northern territories after the end of World War II. At that time, the

27 D. Szymańska, "Wybrane zagadnienia z analizy historycznej i społeczno - ekonomicznej Bornego Sulinowa” [Selected problems in the historical and socio-economic analysis of Borne Sulinowo], Acta Universitatis Nicolai Copernici, Geografia [Geography], vol. XXVIII, Toruń 1996, p. 151. 
settlement action proceeded in a planned manner, under the control of communist authorities, accompanied by the propaganda of returning the ancient Piast territories. Whereas people came to Borne Sulinowo voluntarily, under no duress, spontaneously. The information about the opportunity to live in a new place came mostly from the media, which praised the natural values of the new location and available residences at symbolic prices. The informative action carried out in Upper Silesia by a member of the authorities of Borne at the time was an exception, as a special information point was organised in Katowice. The miners who were laid off (mainly due to mines closing) were told about housing for next to nothing and jobs awaiting them, persuaded they could set up their own businesses there. It coincided with high severance payments for miners. The authorities of Borne wanted to obtain this way significant means for the city's coffers: perhaps even 20 million PLN. Moreover, they counted on the inflow of qualified workers and engineers. It was assumed that about 3.5 thousand would come, but only three hundred did. The settlement process went on. People came to Borne Sulinowo from 36 voivodships of Poland (out of 49 in the administrative division at the time). In its first three years of operation, Borne Sulinowo had a beneficial demographic structure, which promised dynamic development of the town. The largest proportion of the population was aged 40 years or less, $70 \%$ of inhabitants, $23 \%$ were in pre-productive age. The rest were pensioners and children. Moreover, in the town's first years, there was a clearly higher percentage of men in relation to women, 100 to 85 respectively. ${ }^{28}$ The populace was a highly varied conglomeration regarding their region and milieu of origin. The largest group came from West Pomerania, followed by Upper Silesia, Lower Silesia, Greater Poland, Pomerania, and Mazovia. In 1993, the city was assumed to reach 12 thousand inhabitants, yet the reality came out different. According to the data gathered in the research carried out by the Department of Ethnology and Cultural Anthropology of the Adam Mickiewicz University under the direction of Jacek Schmidt in 2005, 2006, 2007, the largest group of immigrants in Borne recruited form the West Pomeranian Voivodship (47\%), the second largest being the newcomers from Silesia (20.6\%), then from Upper Silesia (9.9\%) and Lower Silesia (10.7\%). There were 6.1\% settlers coming from Greater Poland and 3\% from

28 D. Szymańska, "Wybrane zagadnienia z analizy historycznej i społeczno - ekonomicznej Bornego Sulinowa” [Selected problems in the historical and socio-economic analysis of Borne Sulinowo], Acta Universitatis Nicolai Copernici, Geografia [Geography], vol. XXVIII, Toruń 1996, p. 155. 
Mazovia. The numbers of populace from other voivodships did not exceed $3 \%{ }^{29}$ The new settlers were mostly urban population. The most numerous were households set up by arrivals from Szczecin, Szczecinek, Wrocław, Warsaw, Drawsko Pomorskie, Słupsk, Poznań, Koszalin, Świnoujście, Łódź, and the Silesian agglomeration. Migrants from small and medium-sized towns (mostly Pomeranian) set up 251 households; those from large agglomerations, predominantly Szczecin, $450 .{ }^{30}$ Lower Silesians (the group most interesting to us) numbered 312 people, including merely 38 and 274 persons from 22 Lower Silesian villages and 34 towns, respectively; the largest groups came from Wroclaw (44 persons), Lubin (34), Polkowice (32), Wałbrzych (19),Głogów (18), Dzierżoniów (10). The remainder were inhabitants of smaller towns, in groups of no more than 10.3

The new (both culturally and regionally diverse) immigrant community began a long and, as it turned out, difficult process of creating an urban community in new and different spatial conditions. Understandably, the addaptation to the new urban space ran parallel to the integration processes. As follows from the above, Borne Sulinowo presents the elusive, so-called internal multiculrurality. Therefore, how was the new space made familiar, and what were the integration processes like?

\section{PEOPLE AND SPACE}

The new arrivals at Borne Sulinowo encountered an unusual urban space (as mentioned above, the town was constructed as a military base with adjacent practice grounds, which was the overall aim determining the spatial organisation). The town's buildings were dispersed, spread among vast woodland areas, which gave it its nickname of "forest town". Yet, for an outside observer, the well-planned spatial configuration was clearly visible. The main street, now the Independence Avenue (Pol. Al. Niepodlegtości) divided the town in two. The areas north of it, towards the Pile Lake, was where officers lived; it contained mainly villas and other residential buildings. Whereas the areas south of the main street were occupied by barracks, drill

29 J. Schmidt, "Borne Sulinowo - budowanie nowej społeczności w postsowieckiej przestrzeni społecznej” [Borne Sulinowo - Formation of a new community in the post-Soviet social space], in: Etnologiczne i antropologiczne obrazy świata - konteksty i interpretacje. Prace ofiarowane Profesorowi Zygmuntowi Ktodnickiemu w 70. rocznicę urodzin. [Ethnological and anthropological world images - contexts and interpretations], ed. by H. Rusek \& A. Pieńczak, Cieszyn-Katowice 2011, p. 236.

30 J. Schimdt, "Borne Sulinowo - budowanie nowej społeczności w postsowieckiej przestrzeni społecznej" [Borne Sulinowo - Formation of a new community in the post-Soviet social space], in: Etnologiczne i antropologiczne obrazy świata - konteksty i interpretacje. Prace ofiarowane Profesorowi Zygmuntowi Ktodnickiemu w 70. rocznicę urodzin. [Ethnological and anthropological world images - contexts and interpretations], ed. by H. Rusek \& A. Pieńczak, Cieszyn-Katowice 2011, p. 236

31 Data for 2014, prepared by M. Suszczewicz, developed at the Department of Regional and Local Analyses, Institute of Geography and Regional Development, University of Wroctaw. 
grounds, military canteens, and other facilities, complemented by numerous depots, fuel stations, and more remote ammunition depots. The Russians did not interfere with the town's spatial configuration taking it over unchanged (later, buildings from prefabricated concrete appeared, nicknamed "leningrads" by the inhabitants, intended for lower-ranking officers and their families). All extant urban objects in Borne Sulinowo are mute witnesses of the history of the place. The main objective in the first period of settlement was to adapt the buildings for moving in as quickly as possible. An issue arose then how to adapt some of the less typical objects, such as the officers' casino, numerous canteens, cinema-theatre, etc. Let us add that this whole task was left in the hands of the town's authorities and inhabitants, providing them with no technical or organisational assistance. It is worth to depict here the settlement process in the western and northern territories after 1945. The populace arriving then came into contact with a culturally foreign space, unknown technical equipment, lacking skills and knowledge to use it; and even more so with the awareness that what they found was not only foreign but hostile, "not ours". This did not take place in Borne Sulinowo, the process was different. The arrivals at Borne were aware of the foreign cultural heritage of the town, particularly of the alien traces of symbolical culture, sculptures, plaques, monuments, inscriptions left by both armies, etc. The inhabitants are still divided in their attitude towards the objects of foreign heritage. Nevertheless, the priority was to create a town for civilians, enable it to serve urban functions, and adapt some objects for civilian use. The building of the former Soviet HQ became the seat of the Municipal and Town Office, while the old post-Soviet kindergarten was turned into a library, which would also serve as the cultural centre of the town. At present, the object is the seat of many organisations, local circles of artists, writers, Third Age University, and pensioners association. The old hospital building hosts the Town's Social Welfare Centre and the Sclerosis Multiplex (SM) Centre, one of the best in Poland, while the old German post office was adapted for the needs of the "State Forests" Holding. Similar examples abound. As the town's authorities, acting alone (which should be stressed) and without any substantial outside aid, wanted to handle many issues beyond the town's financial capabilities, decided to sell a large number of objects. This plan, while just, did not fully succeed in practice. Alas, the private owners and entrepreneurs who put money in real estate failed to repair them. Consequently, the poor condition (of at least some structures) qualifies them only for demolition. This can be illustrated by the cinema-theatre building, which existed until 2014. The object used to have a well-equipped rotating stage, large auditorium, many rooms, and covered balconies (inside and outside). It was purchased by the University of 
Szczecin. According to the management plan, it was to serve Russian, German, and Polish language schools as well as an in-depth cultural study for the youth from these three countries. Moreover, it was to become a location for interdisciplinary scientific symposiums and conferences. However, the building was completely demolished by the end of 2014. It is interesting that all the extant objects in Borne Sulinowo, while not officially considered as monuments, are legally protected. Was this object lost only due to financial reasons?

Bohdan Jałowiecki writes that urban space is perceived differently by its inhabitants, depending on their status, education, and age. These traits determine the perception, evaluation, and understanding of the space..$^{32}$ Jałowiecki's thoughts can be applied to the community of Borne. The young townspeople were interested in the development of sport and entertainment facilities, while the older ones wanted to preserve the spa nature of the town, with mainly medical services. The attitude of inhabitants to the past history and its related objects was an important factor in the plans of further development and management of the town. Some of the surveyed who saw the town's past as an additional tourist attraction opted for preserving the objects, describing them in detail, and preventing their destruction; others opposed it or were indifferent. The material heritage is perceived by some inhabitants as the inglorious past to be erased in order to create the town anew (as illustrated by the removal of the entrance gates, old watchtowers, and some inscriptions in foreign languages form the urban space). It revealed their attitude to the so-called remembered history. Yet another example of the attitude to historical memory is the case of the Three Cultures Park project developed a few years ago. The project was created by Wiesław Rembieliński, former voivode of Słupsk. The Three Cultures Park was designed as a living museum of the 1930s German culture, the 1960s Russian culture, and the 1990s Polish culture. It would bring together the customs, artistic culture, cuisine, historical spectacles, and souvenir shops. The author consulted his idea with many architects, artists, lawyers, and ecologists. He believed the project would be an interesting and unusual tourist attraction, while providing new jobs (constantly in demand). The local youth, speaking foreign languages, could find employment as tourist guides (not only during holidays). The idea drew much interest of the Dutch, German, and many other visitors in Borne. However, it was not accepted by the authorities and some inhabitants of Borne. While it was appreciated, certain fears arose that the park may become a monument of former occupants and that it would commemorate the infamous presence of two totalitarianisms. Still, it did not have to be so. The author

32 B. Jałowiecki, Globalny świat metropolii [Global world of metropolies], Warszawa 2007, p. 156. 
of the idea perfectly realised that while history cannot be erased it can be used to further the development and promotion of the town. It would seem that the town's inhabitants are divided by a collective memory engrained in their consciousness. It is usually known that people inscribe their dreams and goals in the urban space as the permanent component of memory of a community. ${ }^{33}$ In Borne Sulinowo this process has not ended and is still in its initial phase. Both the establishment of the language school and the Three Cultures Park would exemplify the transformation of the past into the current history of the town. There are many more such examples. The building of the German (then Soviet) casino, nicknamed the "Officer House" by the townspeople, was sold into private hands. Now the state of the object, which in its glory days could be the envy of many a spa town, is critical. Similarly, H. Guderian's villa, a two-storey building with a driveway, now has to be demolished. Germans offered help in its reconstruction, yet the same old political and mental issue appeared again: the aversion to foreign heritage. Why was it so? Why are the material heritage sites unwanted in Borne Sulinowo? Why its inhabitants do not share the view that their presence in the urban space is a historical and cultural treasure not just for the town but Pomerania as well? It seems that memory inscribed in material objects is a reference to specific ideas. Each object carries ideas which are foreign of the current inhabitants, sometimes even hostile, at least for some of them. What takes place here, therefore, is a polarisation of the collective memory, an ongoing process present in the social space of the town.

The seeking and shaping of common collective memory by the town's population is not an easy process, should one consider the existing regional differentiation of the current inhabitants, various goals in life, preferred ways and styles of life: in short, cultural differences. Whereas developing a community of memory, as already mentioned, is one among many conditions to shaping a collective identity. One of the modern non-controversial symbols of the town in its urban space is the Church of Saint Brother Albert; its building used to be a cinema in the Soviet times. The church holds one of the most valuable monuments, a triptych by Jan Zamojski, an artist well-known before the war, who was imprisoned in the nearby camp, the Oflag II D. Another object of similar use is the Carmelite sisters' monastery, dedicated to Madonna of Reconciliation. The monastery's chapel is where two notable symbols of reconciliation are kept: a German crucifix, a gift from a parish priest in Neubrandenburg, and an icon of Madonna of Smolensk, a gift from Russia. The church and the monastery are not just places of prayer: the inhabitants of Borne meet there, and both

33 B. Jałowiecki, Globalny świat metropolii [Global world of metropolies], Warszawa 2007, p. 11. 
are visited by many tourists. It is known that both objects changed their function. Nowadays they serve a narrative purpose, also through their furnishings; they witness the history and, apart from utilitarian aspects, are symbols of the town. Like the building of the library mentioned above, the hospital with the social welfare centre and the cultural-educational building with the small but extremely valuable museum of the recent history of Borne are all examples of material references of the collective memory common to all inhabitants, as well as places of many social interactions. These objects also testify to the selection of the historical memory of Borne Sulinowo and its spatialisation. It is worth noticing that this process is not guided but rather spontaneous, created by the townsfolk.

The adaptation of the inhabitants arriving at Borne to its urban space took place together with the integration of the local community. It is puzzling that after 2005 the inhabitants asked if the town was integrated gave negative answers. What was the role the immigrants from Lower Silesia, the third largerst settlement group, played in the integration of the town?

\section{PROBLEMS WITH INTEGRATION}

The notion of integration in sociological theory takes two basic meanings of social and systemic integration. Social integration refers to a social system understood as the relationship between the parts of the system meant to prevent its dissolution and responsible for the system's functioning. ${ }^{34}$ Therefore, social integration as a process refers to a set of rules, norms, activities of various social groups, in which individuals participating in the social life interact with one another. In simple terms, then, integration means the process of joining, merging things to achieve a new quality. In ethnology, the more commonly used term is cultural integration which defines the relations between the traits of a culture or cultural complexes combining into a new cultural quality. These also include the ties between subcultures within a broader dominant culture, while each subculture retains its distinctiveness. Examples of this are regional and local cultures operating within the framework of a national culture. Integration is a diverse process, both temporally and qualitatively. It involves combining groups of different (local and regional) cultures into a new cultural system, thus requiring an active attitude towards one's own and the foreign culture. Therefore, in this case, culture modifies and stimulates the social integration process. Cultural integration

34 Stownik socjologii [Dictionary of sociology], ed. by G. Marshal, Warszawa 2008, p.127. 
usually initiates the formation of a regional or local community, and is a factor in the shaping of a collective identity.

As mentioned above, the population of Borne Sulinowo is a collective diversified by regional and social origins. In the first years of the functioning of the town, the inhabitants cooperated in harmony, mutual aid was something essential and necessary in order to settle and start a new life. One might think that internal integration of the town's community would quickly be complete. It was not. Since 2005, differences regarding the development plans for the town, concepts of spatial organisation, priorities, and the town's leading functions have begun to appear. Internal integration is not an easy process. It takes many aspects: normative, functional, communication, cultural, and emotional. ${ }^{3}$

Normative integration is, generally speaking, the extent to which a given community adheres to recognised norms and codes of conduct. At present in Borne Sulinowo it is a more advanced plane of integration, there are no social pathologies in the town: robberies, hooliganism, larceny, etc. The listed cases are not an acute problem for the community of the town, the people know one another, which strengthens social control. Moreover, the municipal guards successfully keep the order in town.

Functional integration refers to the activities of individual inhabitants of the city for its benefit, their involvement in its development, actual interest in the town's affairs, and social activism. This integration plane is especially important in regard to accelerated development communities. The activism of the inhabitants of Borne is very high. There are many institutions, organisations, and societies in town, working for the development of the town's community, such as Third Age University, Seniors' Club, a chapter of Polish Fishing Association, a Literary Circle grouping local poets and writers, a choir and a musical bands, two circles of artists, which regularly organise open-air painting workshop, the busy Municipal Public Library, the Cultural-Educational Centre with the Museum Chamber, a foundation of a town museum; there are also many sports, cultural, popular-scientific events, symposiums. Each year, the museum chamber organises meetings of the former prisoners of Oflag II D and their families from France. In August, Borne Sulinowo hosts an international gathering of military history fans, an event with more than three thousand participants. It is beyond doubt that the social activism of a town with no more than four thousand inhabitants is impressive. What is interesting, however, is that in this population-wise small community there are two pensioners' circles and two artistic circles, quite averse towards each other. A question arises why it is the case. The conducted research led to

35 Stownik socjologii [Dictionary of sociology], ed. by G. Marshal, Warszawa 2008, p. 128. 
a number of remarks. Namely, the inhabitants of Borne want things happening in the town, yet they cannot count on financial support of authorities. While most initiatives are bottom-up, not everybody approves of this, which leads to some disagreement. Moreover, some differences may be observed in the attitudes towards various forms of activity between previous inhabitants of cities and people who came from towns and nearby villages. This kind of disputes finds its way to the sessions of the local council. Perhaps this is why many events disappeared form the town calendar.

In the communication aspect, integration understood as the intensity of contacts and relations between groups, takes various forms. The most frequent contacts occur between groups of people coming from the same region or city, e.g., inhabitants of Silesia, Wrocław, Szczecin, or groups of similar age: a group of pensioners, whose numbers are growing in town, holds together. There are far-reaching differences between pensioners and productive age and young people, resulting from different life goals and hierarchies of needs. The pensioners strive to preserve clean environment and silence, while the youth complain of the lack of a cultural offer to meet their needs.

Cultural integration means the degree of agreement of cultural patterns, values, lifestyles, as well as certain norms by which the town's inhabitants abide. It is a moderately advanced and elusive integration plane. A style or way of life is easy to see, as it is manifested outside. However, values are hidden, even though they determine mindsets, certain choices of action, attitudes towards the surrounding reality. The people who came from towns and cities of Upper Silesia is distinguished by initiative, entrepreneurship, is closely integrated, and still maintains parts of its regional traditions. The traditional St. Barbara's Day, celebrated every 4 December, is one such example. It is an event well visible in town. After a Holy Mass in the local church, former miners in dress uniforms march across the city. They go to the "Eagle" restaurant to feast together. As the custom dictates, women are present only until a certain point, then only men remain. Everything is accompanied by regional music and singing. Only the inhabitants coming from Silesia are invited to the event. The Lower Silesians still maintain fragments of the traditions they received from their parents, who migrated from the Eastern Borderlands after 1945. These mainly include family traditions and customs associated with celebrating annual holidays.

Emotional integration, understood as the emotional tie to the town as the place of living is the most advanced. A vast majority of inhabitants, especially those registered for permanent residence identify with the city and its surroundings as their homeland, they even use their own ethnonym, "Borniacy". Whereas there are differences in the assessment of the town's urban space and some objects from the recent past. The planes of internal integration of the community of Borne determine 
and permeate one another, still remaining in the formation stage. Most likely it is so because various "social worlds" take part in the shaping of the community of the town. The notion of social world refers to the social space in which the mutual relations between its participants take place. The limits of the social world are not set by territory or formal participation but rather mutual communication; therefore, social world is a community of communication based on a symbolic system, common to all participants and necessary for interaction and action..$^{36}$ Anna Szyfer adds that a "social world" consists of people sharing the same behavioural patterns, preferred values, and social attitudes. ${ }^{37}$ In a sense, "social worlds" can be understood as cultural worlds, i.e., groups sharing common cultural aims, internally close to each other, with a sense of familiarity. In Borne Sulinowo, there are many coexisting "social worlds" created not just by migrants but also population categories according to age, like pensioners, and people who came to the town to start a new life in a new place, "people with a past", as the locals call them. This state of the social reality still goes on and affects many social processes in the town. Integration problems influence the identification of the socio-cultural local community of Borne Sulinowo. Is the multi-culturalism of the Borne community making this process more difficult, and if so, how does it manifest?

\section{IN SEARCH OF IDENTITY}

There is no doubt that Borne Sulinowo as a local community seeks its own identity and its own place in the cultural space of West Pomerania and Pomeranian history. It should be remembered that West Pomerania is first and foremost an administrative region, not a cultural one as Kashubia, Podhale, or Kurpie. It means that cultural regionalism in this region develops based on local communities or traditional historical enclaves like Pyrzyce. Borne Sulinowo is one of many local enclaves in Pomerania.

According to Helen M. Lynd, a local community is an important system of sociocultural reference and cultural identification. ${ }^{38}$ Szacki attributes three essential traits to a local community: territory, social interaction, and permanent bonds between members of the community. ${ }^{39}$ The existence of a local community does not preclude the presence of various "social worlds" within it or multiculturality. Indubitably, the

36 A. Szyfer, Ludzie pogranicza. Kulturowe uwarunkowania osobowości [People of the borderland. Cultural determinants of personality], Poznań 2005, p. 22-23.

37 A. Szyfer, Ludzie pogranicza. Kulturowe uwarunkowania osobowości [People of the borderland. Cultural determinants of personality], Poznań 2005, p. 23-24.

38 A. Gidens, Nowoczesnosśc i tożsamość. „Ja” i spoteczeństwo w dobie późnej nowoczesności [Modernity and identity], Warszawa 2001, p. 93.

39 J. Szacki, Historia myśli społecznej, op.cit., p. 85. 
place where a local community is shaped is territory, which is the basis of the inhabitants' identification. The inhabitants of Borne show a strong bond with the space of the town: they are not indifferent to spatial organisation or aesthetics. Local environment has always been a permanent part of human surroundings affecting cultural and psychological bonds of its inhabitants. It is there that the specific cultural traits and lifestyle of inhabitants are formed. The locality of Borne Sulinowo is peculiar, being characterised by multiculturalism on the one hand, the coexistence of various "social worlds", and, on the other, common values flowing from the place of residence. It has been shown that the more the surroundings of a residence are attractive, the stronger bonds tie to it. There can be no doubt that the urban space which has become one of essential environmental and historical values plays an important role in shaping the collective identity. It is evidenced by the active presence of the local artists, poets, and writers, whose art focuses on the values of the town and its vicinity. The space of the town and its surroundings also yields measurable material gain in the form of fishing, game, undergrowth products, and wood. Whereas the urban space provides knowledge about the town's historical past. Taking advantage of its environmental and historical values, the authorities and inhabitants of Borne Sulinowo tried many times to organise multiple events, mentioned above, in order to more fully integrate the inhabitants. They did not always succeed. The annual "Honey and Bread Fair", International Firefighter Diver Championship, the Zygmunt Weiss Raid On the Evacuation Route of Oflag II D POWs are all recreational and educational events which involve more visitors from the outside than the local community. A very important role in the formation of the local social identity belongs to the school and parish. Both institutions offer a wide range of well thought-out activities for children and youth in regional and pro-ecological education, upbringing, and developing civic attitudes. The problem is, however, that local youth who graduate from their studies do not include returning to Borne in their life plans. It is undeniable, however, that both local authorities and active inhabitants of the town spare no effort in creating local identity. Rather than that, what can be observed at this point is the so-called liquid identity, still at the stage of forming, seeking references. An example of this is the project, carried out by the Municipal Office, entitled "History among nature". Its main concept is to combine ideas from the recent history of the town with ecology. The town is struggling with a basic problem: it seeks the answer to the question if Borne should be a predominantly tourist town, which requires investment and exceeds the capabilities of the local authorities. Should it then be a town-monument of recent history, certainly the history of Europe, or should it be a town for retirement age people, its function that of a spa? Or should it become a dormitory suburb of the 
nearby Szczecinek (over 30 thousand people)? The latter would, by its very nature limit the town's development. ${ }^{40}$ There is no unequivocal answer to these questions. When Borne Sulinowo was granted the town status, its development plants assumed that the population of the town would reach 12 thousand inhabitants. In fact, however, Borne never exceeded 5 thousand people. The number of inhabitants always oscillates around 4.5 thousand. It should be added, that similar garrison towns in the former GDR are demolished completely, and no attempts to revive them are made.

Even though Borne Sulinowo is a small town, counting its population, deprived of external support from the very beginning, it has been built and organised with a great human effort, is a real geographic area and socio-cultural and symbolic space with which its inhabitants identify in spite of certain differences how to understand and experience this space. The inhabitants of borne create and fill this space, integrate the past with the present, and seek the future. Which gives rise to the question, which factors hinder and facilitate this? Why are there still internal integration problems, difficulties in shaping the socio-cultural collective identity, and differences in developmental concepts for the town?

\section{FUNCTIONAL MEMORY AND STORAGE MEMORY: THE CASE OF LOWER SILESIANS}

The creation of the social reality of Borne Sulinowo has been and is affected by many major factors, shortly discussed above. It seems that the most significant ones include the collective memory of the inhabitants as it sets the limits of the world of knowledge and is one of many components of everyday life.

As has been mentioned, the collective memory in the community of Borne Sulinowo is in its formation stage. On the one hand, it functions as the memory brought by various social groups which took part in the creation of the town and, on the other hand, it participates in the formation of the memory shared by all inhabitants which is an essential factor in the shaping of collective identity. Borne Sulinowo is a fascinating site of Pomeranian, Polish, and European history. It is a genius loci, i.e., objective space with remnants of a cultural heritage which, due to its past, becomes something important and significant (not only for its current inhabitants). To some extent, it may also be a so-called topophilia, or a place filled with the "spirit" of the inhabitants who endow it with an emotional value, positive or negative, as Yi Fu Tuan wrote (among

40 Katarzyna Kajdanek gave a broader description of suburbia as a phenomenon of qualitatively new inhabited space can be found in: K. Kajdanek, Suburbanizacja po polsku [Suburbanisation, Polish way], Kraków 2012. 
others) explaining the ties between humans and environment. ${ }^{41}$ A place not filled with any "spirit" becomes a dead place, according to the author of the individualistic idea of place and space. Borne Sulinowo is now inhabited by people from the post-war-witness generation, who know war only from their parents and grandparents' tales. The third most numerous group of inhabitants are Lower Silesians, 312 of whom arrived in the first formation years of the town; the largest group of them came from Wrocław, the others from cities, towns, and villages of Lower Silesia. An overwhelming majority of them was born, grew up, and spent most of their in Lower Silesia. As descendants of the settlers on the western and northern territories, they lived in the conditions of socialist Poland and the transformation period, gaining social and individual experience as well as the knowledge about the past of a region with a specific history and culture.

The western and northern territories had to redefine their identity, which involved the inhabitants of these lands. This task employed the official interpretation of history and historical memory, enforced by the state authorities.

Wrocław and Lower Silesia have always been multicultural areas due to the past of the region, both remote and recent. In the first years after the war, the life of Lower Silesian towns and villages was being built anew, just like in Borne Sulinowo 48 years later. What was most jarring, it was the memory of the German cultural heritage. Therefore, it was being destroyed for many reasons, including sense of hostility, psychological reaction to the suffering ow war, as well as indoctrination from the authorities. First of all monuments were destroyed, as sites preserving collective memory, public utility buildings, some of which were turned into warehouses, and Lutheran churches into cultural centres. Anything that did not refer to the new reality was being destroyed in the conviction that without any proof of material cultural heritage, the collective memory of this heritage would also disappear. Sadly, German cemeteries were demolished, their precious headstones being used in many ways, including the stairs leading to the ZUS building in Wrocław or the floor in the Burghers' Hall in the Wroclaw Town Hall..$^{42}$ There are many more examples of similar instrumental use of memory. The present-day inhabitants of Borne Sulinowo hailing from Lower Silesia know them from the tales of their parents and grandparents. While they may have witnessed these events, they may not always have understood them due to their young age. Nevertheless, the results of manipulating the historical facts for ideological purposes, and thus manipulating the memory, can be seen even today and not just

41 M. Pirveli, "Duch miejsca a topofilia” [Spirit of place and topophilia], in: Pamięć, przestrzeń, tożsamość [Memory, space, identity], ed. by S. Kapralski, Warszawa 2010, p. 221.

42 I. Kaczmarek-Murzyniec, "Europejska wielokulturowość a procesy identyfikacji regionalnej Dolnoślązaków” [European multiculturality and regional identification processes of Lower Silesians], in: Oblicza europejskiej tożsamości [Faces of European identity], ed. by R. Suchocka, Poznań 2001, p. 195. 
in Lower Silesia. After the post-1989 transformations, the idea of regionalism was revived in the whole country, including the former western territories. Here, the situation was compounded by the fact that the German cultural heritage was still there, to a large extent, in spite of purposeful destruction. Such regions as Lower Silesia and West Pomerania accepted is as legacy culture goods, displaying the cultural wealth of both regions. The changes in both school and extramural education system regarding the content taught and teaching tolerance towards other nations and cultures were also important. A good example of the changes taking place in the consciousness of inhabitants of many towns and villages is the event which occurred in Nakomiady in 2005. Nakomiady is a post-state farm village in the Warmian-Masurian Voivodship. A monument to Otto von Bismarck was uncovered there, a man well-known in the history of Poland as a foe of Poles. Acting as the local self-government, the inhabitants of the village decided to place the obelisk in its centre, in spite of numerous protests from voivodeship authorities and a negative opinion of the Council for the Protection of Struggle and Martyrdom Sites. The interesting fact is that the inhabitants did not want to glorify the man but rather restore the historical appearance of the village, saying that the obelisk is part of its genuine cultural heritage and landscape of old. The decision was made by the inhabitants by democratic vote. ${ }^{43}$ This event shows that it is the local community of inhabitants who decides what takes place in the social space of a town or a village, who verifies the remembered history and historical memory by itself.

From the viewpoints of anthropology and sociology, the attitude towards the past and foreign cultural heritage may take form dependent on various causes:

it can be considered one's own, determined by the so-called long duration; it can be considered part of European, not just German culture;

it can be considered as part of historical and objective landscape of the region, without engaging negative emotional attitudes. ${ }^{44}$

Has any of these causes occurred, or is present, in the community of Borne Sulinowo? The research as well as conversations with the inhabitants confirm that none is. The people who came to Borne accepted the new place sparing no effort to give the town a hospitable form. The demolishing of object and eradication of memory was not the inhabitants' work but rather an unoficial task of the previous local authorities.

43 D. Chmielewski, "Wielokulturowość lokalnego systemu społeczno - kulturowego: Przykład wsi Nakomiady" [Multiculturality of the local socio-cultural system: The example of Nakomiady village], Kultura w Europie od tradycji do zjawisk wspótczesnych [Culture in Europe from tradition to present phenomena], ed. by K. Izdebska, Szczecin 2009, p. 73.

44 I. Kaczmarek-Murzyniec, “Europejska wielokulturowość a procesy identyfikacji regionalnej Dolnoślązaków” [European multiculturality and regional identification processes of Lower Silesians], in: Oblicza europejskiej tożsamości [Faces of European identity], ed. by R. Suchocka, Poznań 2001, p. 196. 
They strove then to sell the exisiting objects as quickly as possible to gain money for the town's coffers or demolish them and use the material for the roadbuilding, not necessarily in Borne or its vicinity.

Lower Silesians are the third most numerous regional group in the town. One would expect that, knowing the social processes in Lower Silesia both from stories and own experience, they would be an active, socially coherent group, with an already formed attitude towards the heritage found in Borne Sulinowo. However, the conducted research shows that the people who came to Borne from Lower Silesia are not a coherent regional group, do not identify with one another by their origins. Only small groups composed by a few families know one another, who came from the same town or village and continue their old neighbourhood bonds and family traditions, mostly related to family and religious celebrations, in a new place.

The above situation is almost identical as in Lover Silesia in the previous years. More than $80 \%$ of the surveyed say that, in the towns and villages of their origin, only a few families maintained close social relations, usually originating from the same area before 1945. It is puzzling how this phenomenon was transferred, one generation apart. The same respondents, asked when the full internal integration of Lower Silesia took place, usually name the 1970s and 1980s. What is interesting, however, is the attitude of the Lower Silesians to foreign cultural heritage. The majority of the surveyed say that in the first years of settlement, both in Wroctaw and other towns and villages of Lower Silesia, the remnants of German cultural heritage were not destroyed. It happened rarely and usually involved symbols, i.e., plaques, inscriptions, and well-known monuments which raised no doubts. The destruction and eradication of historical memory began later, in the 1960s, according to the majority of respondents. The majority also states that the attitude of the German population who remained in Lower Silesia towards the settlers was friendly and helpful. Perhaps this is the reason why the Lower Silesians in Borne Sulinowo show a positive attitude towards Germans and Russians, without judgments based on cultural stereotypes. The attitude of Lower Silesians to the remaining objects of German and Russian architecture is positive as well. Most of the surveyed agree to maintain them as the material heritage of a unique town, and not to erase the historical memory which is a concrete fact. A large number of the participants say that the recent history of the town should be displayed for the tourist, in particular to the youth, as a form of witnessed education not limited to a region. Other inhabitants of Borne Sulinowo share similar views. Asked for cultural symbols and symbolical sites in the present-day town, the studied group usually named the coat of arms and the already adapted objects: the Carmelite monastery, church, Museum Chamber, as well as sites of peculiar history: the Officer House and the 
ruins of H. Guderian's villa. Some people asked about the most expressive symbols named the ruins from the past historical periods, German and Soviet, and justified their replies saying that at least some of them should be preserved as the evidence of the actual history of the town. Here the former railway station was named, with the platform where Adolf Hitler got off the train to visit Gross Born, and so did the Red Army high commanders after 1945. Interestingly, not a single respondent named the newly constructed sport and recreation sites, new boarding houses, etc., whereas the local cemeteries are treated by the inhabitants of Borne Sulinowo as sites of special symbolic significance. There are six of them in the town and its closest vicinity. The town has a municipal cemetery, and there are two more post-Soviet cemeteries close to it, a war cemetery, where young Russian soldiers and children ( 2 or 3 years old) of Russian military families. Children's toys, donated by the children and youth of Borne, are placed on their graves. There is also a POW cemetery from the times of war nearby. The woods near Kłomino hide three cemeteries of prisoners of war from nearby camps, including the Oflag II D. The local population spontaneously cares for all these sites, from an internal need to care for the places of burial. A cemetery expresses the philosophy of passing, divides the worlds of the living and the dead. In all cultures, it is a place of the so-called sacrum, linking the past and the present.

The cemeteries in Borne Sulinowo preserve the memory of the place and, beyond doubt, function in the collective memory of the inhabitants.

The people from Lower Silesia are not distinguished by anything special from the local community of Borne. However, they harbour a certain jealousy, not shown yet experienced, towards the group from Upper Silesia. The Upper Silesians are integrated, manifest their origins, and are very active in the surroundings. This is due to the origins of both groups. As a region, Upper Silesia is incomparable to the other represented in the town. As a region, it enjoyed an unbroken settlement continuity and developed an original culture over the years, which became the foundation of the Silesian and national identities. As a very important plane of socialisation and upbringing, the culture of the inhabitants coming from Upper Silesia was also brought to Borne, e.g., in the form of St. Barbara's Day. The Lower Silesian inhabitants, from a region with a radically different history and broken settlement community, came to Borne Sulinowo with the so-called "brought in" collective memory based on various experiences of diversified locality, largely educated by various institutions and family circles. Much of the same may be said about the numerically predominant group in the city, i.e., the population coming from West Pomerania. The Lower Silesians living in Borne Sulinowo had various local identities tying them to the place they came from; this feeling has remained. It may be the reason why, unlike the inhabitants from Upper 
Silesia, they are not a coherent regional group but rather smaller, atomised groups. Anyhow, by inhabiting a multicultural region before coming to Borne, they mastered the skill of tolerance and respect towards the past without labelling it as better or worse. Now, living in Borne Sulinowo, they show a positive attitude to the existing cultural heritage. The majority of respondents, asked about the projects of the Three Cultures Park and Three Cultures Festival, approved of the suggested ideas. However, some of them expressed some concerns related to the changing political situation. Still, their attitude to the new place of residence and its surroundings is unanimous. All newcomers praise its environment and climate, treating the town as their own, not foreign. Many of them considered moving to West Pomerania for health reasons even before Borne Sulinowo was founded. These are mainly former inhabitants of Polkowice, Lubin, Wałbrzych, and Wrocław, who worked in the industry. The studied population is currently composed of people aged 60 or older, who simply look for calm. For the inhabitants from Lower Silesia, Borne Sulinowo is both a material and immaterial value, it is perceived as their new "small homeland", in the terms of Stanistaw Ossowski. ${ }^{45}$ More and more people know the history of Borne Sulinowo, seek ways how to apply it to the present and future of the town, thus looking for a full integration of the town's past with its present and future. This process is constant. The differences in opinions arising when carrying it out attest to strong emotional ties with the town, whose present condition and future fates are not unimportant. J. Assmann wrote about the relation between the communication memory and cultural memory. The former comes to being in the oral intergenerational transmission. The older generation passes its experience and knowledge to the younger ones. ${ }^{46}$ This process took place in the western and northern territories after 1945, while the current inhabitants of Borne Sulinowo (Lower Silesians), among others, were its participants. When they arrived at Borne Sulinowo in the 1990s, they encountered a new space and foreign cultural heritage, as their parents had years ago in the Lower Silesian land. The adaptation to the new space of the former garrison town took some 10-15 years, until they slowly started seeing it as their chosen place. The process of creating a cultural memory, or local commemoration of history, had begun. J. Assmann, quoted above, writes that cultural memory arises when the witnesses of history pass away and the past has to be made permanent in the external space. ${ }^{47}$ It has been taking place for 20 years in many towns and cities in Poland: Szczecin, Wrocław, Gdańsk, and smaller municipalities

45 S. Ossowski, O ojczyźnie i narodzie [Homeland and nation], Warszawa 1984, p. 18.

$46 \mathrm{~J}$. Assmann, J. Assmann, Pamięć kulturowa. Pismo, zapamiętywanie i polityczna tożsamość w cywilizacjach starożytnych [Cultural memory and early civilisation: Writing, remembrance, and political imagination], transl. by A. Kryczyńska-Pham, Warszawa 2008, p. 13-16.

47 Ibidem. 
in western Poland, where artefacts of German origin, treated as a common historical and cultural heritage, return to the cultural memory. It is similar in Borne Sulinowo.

Aleida Assmann introduces the notions of storage and functional memory, which supplement the theory of the famous Egyptologist and historian. ${ }^{48}$ Storage memory is a set of elements of the past which are inactive, unused, moved aside, which does not mean rejected. Whereas functional memory is the active and selected memory. It refers to a certain social group and participates in its everyday life. One could expect that all the above examples of memory are now present in Borne Sulinowo. Storate memory exists parallel to functional memory, which is typical of modern societies, particularly those, I believe, which took part in the process of system transformation. The memory lives in the local community of the town, is made permanent in the social transmission, and, most importantly, is not an enforced memory but co-created by the inhabitants of the town.

\section{CONCLUSION}

Borne Sulinowo is, beyond doubt, a unique town both socially and culturally. In its short history of but 22 years since it received the status of a town, many changes took place in its population, economy, society, and culture. The socio-cultural processes, initiated 22 years ago, which aim at finding directions of development for the urban community, are still running. Little has been written recently about Borne Sulinowo, its unique history, and transformations taking place in the town. Some publications are pessimistic, yet it is difficult to agree with them. They indicate, e.g., the disillusionment of people who came to Borne, significant loss of jobs, which is a problem that is not specific to Borne, just like the migration of the youth looking for better places to live. It is also difficult to agree with the thesis that the town lost much of its social capital from the initial formational period. Some publications even expressed the opinion that Borne Sulinowo should disappear from the map of Poland due to its infamous history. The majority of such opinions were usually found in external publications, written far from Borne Sulinowo and not necessarily scientific. The conducted research contradicts such opinions. Borne Sulinowo is going to retain its unique and attractive character due to its rich and unique environment and unprecedented history. While it is a fact that the inhabitants of the town are mostly pensioners, they are people rich in life experience, who are the underestimated and inalienable social capital of the town. Moreover, they have done much for the town and still do. They are the local artists,

48 A. Assmann, Erinnerungsraume: Formen und Wandlungen des kulturellen Gadachtnisses, Munchen, 1999, p. 134. 
musicians, writers, and poets, authors of the local cultural achievements, dedicated to the town. One such person is Mirosława Łuczak who lived in Borne from its beginning and who performed enormous work for children, youth, and adults, changing their attitudes to the new place through her cultural and educational activities, in spite of many difficulties. She wrote two books which, while being personal memoirs, describe in detail the events and the climate of the new local community in formation. One of them, bearing the reflective title Borne Sulinowo, such a place still exists... describes the everyday life of its inhabitants in the initial period, when the first courageous people were arriving.

Borne Sulinowo "did not sleep through its historical moment", was the opinion expressed by many people in the study. Simply put, there was no such moment, $\mathrm{n}$ real aid from the voivodship or central authorities. Today the town belongs to its inhabitants, has created a social climate of its own. It builds its own identity in the passing time using both the brought in memory and that found in the space of the town. The latter becomes the stuff of symbolic culture, like the coat of arms, the objects mentioned above, cemeteries, etc. It is an identity culture: the inhabitants constantly refer to the remnants of cultural heritage, attaching a different interpretation to it in order to both identify themselves and the provide identification to their place. Therefore, "Borniacy" create and monitor the form of their culture through the lens of memory. This way the peculiar meta-culture of Borne Sulinowo creates and develops itself. It might be right to refer to St Augustine here, who said ages ago that memory is the now of the past.

\section{TRANSLATION: Andrzej PIETKIEWICZ}

BIBLIOGRAPHY:

Assmann A., Przestrzeń pamięci. Formy i przemiany pamięci kulturowej [ni:] Pamięć zbiorowa i kulturowa. Wspótczesna praktyka niemiecka, red. nauk. M. Syriusz - Wolska, Kraków, 2009.

Assmann J., Pamięć kulturowa. Pismo zapamiętywanie i polityka tożsamości w cywilizacjach starożytnych, Warszawa, 2008.

Bokszański Z., Tożsamość - Interakcja - Grupa. Tożsamość jednostki w perspektywie teorii socjologicznej, Łódź, 1989.

Burszta W.J., Różnorodność i tożsamość. Antropologia jako kulturowa refleksyjność. Poznań, 2004.

Chmielewski D., Wielokulturowość lokalnego systemu społeczno kulturowego. Przykład wsi Nakomaidy, [ w: ] Kultura w Europie, od tradycji do zjawisk wspótczesnych. Refleksje socjologiczne, red. nauk. K. Izdebska, Szczecin, 2009.

Delpech T., Powrót barbarzyństwa w XXI wieku. Warszawa, 2008.

Dobrowolski K., Studia nad życiem społecznym i kulturą. Wrocław - Warszawa - Kraków, 1966. Erikson E.H., Tożsamość a cykl życia. Poznań 2004. 
Giddens A., Nowoczesność i tożsamość, „Ja” i spoteczeństwo dobie późnej nowoczesności. Warszawa, 2006. Gniazdowski A., Wspólnota i świat. Tożsamość spoteczności lokalnej jako temat fenomenologii, [ w:] Oblicza lokalności. Tradycja i współczesność, red nauk. J. Kurczewska, Warszawa 2006.

Holbwachs M., Spoteczne ramy pamięci. Warszawa, 1969.

Jałowiecki B., Globalny świat metropolii. Warszawa, 2007.

Kajdanek K., Suburbanizacja po polsku. Kraków, 2012.

Kosseleck R., Semantyka historyczna. Poznań, 2012.

Korzeniewski B., Transformacja pamięci. Przewartościowania w pamięci przeszłości a wybrane aspekty funkcjonowania dyskursu publicznego o przyszłości w Polsce po 1989 roku. Poznań,2010.

Nurek S., Idea spoteczności lokalnej w tradycji i wspótczesnej refleksji socjologicznej, [w:]Spoteczności lokalne. Szkice socjologiczne, red. nauk. J. Wódz, Katowice, 1986.

Ossowski S., O ojczyźnie i narodzie. Warszawa, 1984.

Pirveli M., Duch miejsca a topofilia, [w: Pamięć, przestrzeń, tożsamość, red.nauk. S. Kapralski, Warszawa, 2010.

Ricouer P., Pamięć, historia, zapomnienie. Kraków, 2012.

Schmidt J., Borne Sulinowo - budowanie nowej społeczności w postsowieckiej przestrzeni spotecznej, [w:] Etnologiczne i antropologiczne obrazy świata - konteksty i interpretacje. Prace ofiarowane profesorowi Zygmuntowi Kłodnickiemu w siedemdziesiąta rocznicę urodzin, red. nauk. H. Rusek, A.Pieńczak, Cieszyn - Katowice, 2011.

Szyfer A., Ludzie pogranicza. Kulturowe uwarunkowania osobowości. Poznań, 2005.

Szymańska D., Wybrane zagadnienia z analizy historycznej i spoteczno ekonomicznej Bornego Sulinowa, Acta Universitatis Nicolai Copernici, Geografia, t. XXVIII, Toruń, 1996.

Szacki J. Historia myśli spotecznej, T. 2, Warszawa 198.

Szacki J., Tradycja. Przegląd problematyki. Warszawa, 1971.

Taylor Ch., Źródła podmiotowości. Narodziny tożsamości nowoczesnej. Warszawa, 2005.

Zwykty żotnierski los, jeńcy wojenni n Pomorzu Zachodnim (199 - 1945) red. nauk. Aniszewska J., Kobylarz-Buly R., Stanek P., Opole 2011 